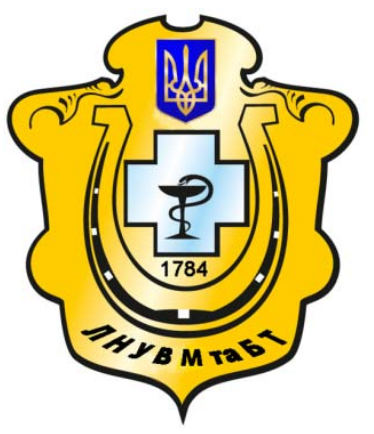

Науковий вісник Львівського національного університету ветеринарної медицини та біотехнологій імені С.3. Гжицького

Scientific Messenger of Lviv National University of Veterinary Medicine and Biotechnologies named after S.Z. Gzhytskyj

doi:10.15421/nvlvet7019

ISSN 2413-5550 print

ISSN 2518-1327 online

$\underline{\text { http://nvlvet.com.ua/ }}$

УДК 006.063:637.524

\title{
Аналіз ризиків та критичних контрольних точок (НААСР), при виробництві м'ясних ковбас на ПП «Стрийські делікатеси»
}

\author{
О.О. Дашковський, В.3. Салата \\ salatavolod@ukr.net
}

Львівський національний університет ветеринарної медицини та біотехнологій імені С.3. Гжищького, вул. Пекарська, 50, м. Львів, 79010, Украӥна

Ковбасні вироби відносять до основного виду м'ясних продуктів. Велике значення і розповсюдження ковбасних виробів пояснюється їх високою харчовою иінністю, калорійністю, можливістю вживання в їжу без додаткової кулінарної оброб$\kappa и$, значним терміном зберігання та можливістю до транспортування на значні відстані. Під час виготовлення ковбас із сировини видаляють частини, які мають низьку харчову иінність (кістки, з'єднувальна тканина), $і$ додають речовини, иінні в харчовому відношенні (молочні вироби, кров'яні вироби та ін.) $і$ які мають гарні ароматичні та смакові властивості (спеції та ін.). Практично кожен продукт харчування, який включає в технології виготовлення елемент складання рецептури, може бути віднесений до комбінованого, характерні ознаки і показники якого будуть визначатись переважним вмістом в рецептурі продукту визначеного сировинного компонента і технологією виготовлення. Тому в деяких краӥнах продукти, що виробляються м'ясопереробною галуззю, класифікуються на м'ясні, комбіновані м'ясопродукти, м'ясорослинні (на м'ясній основі) та аналоги м'ясних. Головною умовою можливості реалізації продукту харчування лишається досягнення його безпечності при споживанні людиною.

Під поняттям «безпечність» розуміється гарантія того, що в повному ииклі виробництва, постачання та в термінах зберігання продукт не завдасть шкоди здоров'ю споживача.

Стаття 20 Закону України «Про безпечність та якість харчових продуктів» № 2809-IV від 6 вересня 2005 р. встановлює вимогу до осіб, які займаються виробництвом або введенням в обіг харчових продуктів, застосовувати санітарні заходи та належну практику виробництва, систему НАССР та/або інші системи забезпечення безпечності та якості харчових продуктів під час виробництва та обігу харчових продуктів. Практично у всіх краӥнах світу до виробників харчових продуктів висуваються аналогічні вимоги.

Враховуючи можливі перспективи і розширення ринків збуту, вітчизняним підприсмствам необхідно ширше впроваджувати системи сертифікаиї (безпеки) продукції згідно з рекомендаціями міжнародного законодавства в сфері сертифікації харчових продуктів ( ISO 22000:2005), системи Еигер GAP контролю в рослинництві, систему контрольних точок для тваринництва і виробництва харчових продуктів - Hazard Analysis Critikal Control Points (НАССР), яка перекладається, як «аналіз небезпек $і$ критичних контрольних точок». Основною метою статті є проведення аналізу безпечності харчових продуктів, зокрема варених ковбас, аналіз наявності небезпечних чинників на всій ланці виробничого ланцюга на прикладі ПП «СМІО» «Стрийські делікатеси».

Ключові слова: якість, система управління безпечністю харчових продуктів, небезпечний чинник харчового продукту, м'ясні вироби, варені ковбаси, ризик, безпечність, критична точка керування, критичні межі.

\section{Анализ рисков и критических контрольных точек (НААСР), при производстве мясных колбас на ООО «Стрыйские деликатесы»}

\author{
О.О. Дашковский, В.3. Салата \\ salatavolod@ukr.net
}

Львовский национальный университет ветеринарной медицины и биотехнологий имени С.3. Гжицєкого,

\footnotetext{
Citation:

Dashkovskyy, O., Salata V. (2016). Hazard analysis and critical control points (HACCP), the production of meat sausages on p.c. «Stryjsky meats delicious». Scientific Messenger LNUVMBT named after S.Z. Gzhytskyj, 18, 3(70), 83-87.
} 
Колбасные изделия относят к основному виду мясных продуктов. Большое значение и распространение колбасных изделий объясняется их высокой пищевой ценностью, калорийностью, возможностью употребления в пищу без дополнительной кулинарной обработки, значительным сроком хранения и возможностью к транспортировке на значительные расстояния. При изготовлении колбас из сырья удаляют части, которые имеют низкую пищевую ценность (кости, соединительная ткань), и добавляют вещества, иенные в пищевом отношении (молочные изделия, кровяные изделия и др.) и те которые владеют хорошими ароматическими и вкусовыми свойствами (специи и др.). Практически каждый продукт питания, который включает в технологии изготовления элемент составления рецептуры, может быть отнесен к комбинированным, характерные признаки и показатели которого будут определяться содержанием в реиептуре продукта определенного сырьевого компонента и технологии изготовления. Поэтому в некоторых странах продукты, производимые мясоперерабатывающей отраслью, классифицируются на мясные, комбинированные мясопродукты, мясорастительные (на мясной основе) и аналоги мясных. Главным условием возможности реализаџии продуктов питания является достижение их безопасности при потреблении человеком.

Понятие «безопасность» включает гарантию того, что в полном ијикле производства, поставки и в терминах хранения продукт не нанесет вреда здоровью потребителя.

Статья 20 Закона Украины «О безопасности и качестве пищевых продуктов» № 2809-IV от 6 сентября 2005 устанавливает требование к лииам, которые занимаются производством или введением в оборот пищевых продуктов, применять санитарные меры и надлежсамую технологию производства, систему НАССР и / или другие системы обеспечения безопасности и качества пищевых продуктов при производстве и обороте пищевых продуктов. Практически во всех странах мира к производителям пищевых продуктов выдвигаются аналогичные требования.

Учитывая возможные перспективы и расширения рынков сбыта, отечественным предприятиям необходимо шире внедрять системы сертификаџии (безопасности) продукиии в соответствии с рекомендациями международного законодательства в области сертификачии пищевых продуктов (ISO 22000: 2005), системы Еигер GАР контроля в растениеводстве, систему контрольных точек для животноводства и производства пищевых продуктов - Hazard Analysis Critikal Control Points (НАССР), которая переводится, как «анализ опасностей и критических контрольных точек».

Основной целью статьи является проведение анализа безопасности пищевых продуктов, в частности вареных колбас, анализ наличия опасных факторов во всем звене производственной цепочки на примере ООО «СМИО» «Стрыйские деликатесы».

Ключевые слова: качество, система управления безопасностью пищевых продуктов, опасные риски пищевых продуктов, мясные изделия, вареные колбасы, риск, безопасность, критическая точка управления, критические предель.

\title{
Hazard analysis and critical control points (HACCP), the production of meat sausages on p.c. «Stryjsky meats delicious»
}

\author{
O. Dashkovskyy, V. Salata \\ salatavolod@ukr.net

\begin{abstract}
Lviv national university of veterinary medicine and biotechnologies named after S. Gzhytskyj, Pekarska Str., 50, Lviv, 79010, Ukraine
\end{abstract}

Meats include the main type of meat products. Great value and distribution of sausages due to their high nutritional valuation, calorie consumption opportunity without culinary processing a significant shelf life and the ability to transport over long distances. During the production of raw sausages remove parts that have low nutritional value (bones, connective tissue), and add substance to nutritionally valuable (dairy products, blood products, etc.) And have a good aroma and flavor properties (spices, etc.). Almost every food product that includes technology production element assembly recipes, can be attributed to the combination characteristic signs and indicators which will be determined in the primary content of the recipe specified product raw materials and manufacturing techniques. Therefore, in some countries, the products produced by the meat processing industry, classified on meat, meat combination, cereal (based on meat) and meat analogues. The main condition for the feasibility of achieving food remains its safety when consumed by man.The term "safety" means a guarantee that the full cycle of production, supply and storage of the product in terms not harm health.

Article 20 of the Law of Ukraine «On the safety and quality of food» № 2809-IV of 6 September 2005 the requirement for persons engaged in the production or introduction into circulation of foodstuffs, apply sanitary measures and good practices of production, HACCP system and / or other systems to ensure safety and quality of food during the production and circulation of food. Almost all countries to food producers put forward similar demands.

Due to possible prospects and expand markets, fatherland, his enterprises must increasingly implement certification system (security) product line with the recommendations of international legislation on the certification of food products (ISO 22000: 2005) systems Eurep GAP control in the crop, a system of control points for livestock and food production - hazard analysis critical control points (HACCP), which translates as "hazard analysis and critical control points». The main purpose of the article is the analysis of food safety, including cooked sausages, analysis of the presence of hazards throughout the production chain link on the example P.C. «SMIO» «Stryjsky meats delicious»

Key words: quality management, system food safety, hazards food, meat products, cooked sausages, risk, safety, critical control points, critical limits. 


\section{Вступ}

Міжнародний досвід свідчить, що тільки завдяки зведенню проблеми якості на рівень національної ідеї можна не тільки перебороти економічну кризу, але і зайняти ведучі позиції на світовому ринку. Сьогодні багато країн визнають проблему якості одним із пріоритетних напрямків своєї діяльності (Klymenko, 2006; Dyman' and Mazur, 2011).

Найсучаснішою попереджувальною системою, що забезпечує якість і безпеку харчової продукції, сьогодні $є$ система на основі принципів НАССР. Аналіз ризиків і точок критичного контролю НАССР - це застережлива система безпеки, яка використовується в харчовій промисловості як гарантія збереження продуктів. Ця система визначає систематичний підхід до аналізу обробки продуктів харчування, розпізнавання будь-яких можливих ризиків хімічного, фізичного і біологічного походження і їх контролю. Протягом останнього року вітчизняна харчова промисловість розвивається дуже динамічно. Ця тенденція безумовно є позитивною, тому що визначає формування зрілого внутрішнього ринку харчових продуктів, посилення конкуренції та зростання якості. Дійсно, при можливості більшого вибору претендувати на споживчий попит може лише товар, котрий відповідає високим вимогам якості (Belov, 2005; Davleev and Versan, 2012; Topol'nyc'kyj, 2013).

Безпечність харчових продуктів пов'язана 3 наявністю небезпечних чинників у харчових продуктах на момент споживання (вживання споживачем). Оскільки небезпечний чинник харчового продукту може з'явитися на будь-якій ланці харчового ланцюга, адекватне керування в усьому харчовому ланцюгу $є$ суттєво важливим. Отже харчові продукти можна зазпечити спільними зусиллями всіх сторін, що беруть участь у харчовому ланцюгу (DSTU 4261-2003; ISO 22000).

Харчовий ланцюг охоплює різноманітні організації, від виробників кормів та первинної продукції до виробників харчових продуктів, операторів з транспортування та зберігання і субпідрядників, і далі до підприємств роздрібної торгівлі та закладів громадського харчування (разом із суміжними організаціями, такими як виробники устатковання, пакувальних матеріалів, мийних засобів, добавок та інгредієнтів). Такий ланцюг охоплює також організації 3 надання послуг (Alehina and Bol'shakov V.G., 2012; ISO 22000; ISO 9001:2000).

\section{Матеріал і методи досліджень}

Будь-яка галузь харчової промисловості не зможе успішно працювати без діючої НТД. Тому, щоб виробляти м'ясо-ковбасні вироби високої якості, першочерговим завданням є забезпечення м'ясопереробної галузі нормативною документацією, опрацьованою та гармонізованою відповідно до вимог комісії Кодекс Аліментаріус та до міжнародних стандартів, а також розроблення проектів технічних регламентів, які базуються на директивах $\mathrm{CC}$, на весь м'ясопереробний комплекс України.

\section{Результати та їх обговорення}

Об'єктом дослідження є сучасний стан застосування системи НАССР на ПП «СМiO» при виробництві варених ковбас. Виробництво безпечної продукції вимагає, щоб система НАССР була побудована на міцній основі програм - передумов. Кожний сегмент харчової промисловості має забезпечити умови, необхідні для захисту харчових продуктів, що знаходяться під їх контролем.

Формат планів НАССР може змінюватися. У багатьох випадках плани НАССР $є$ специфічними для продукції та процесу. Проте деякі плани використовують один підхід до дій. Загальні плани НАССР можуть служити корисною настановою в розвитку процесу та НАССР; проте важливо, щоб унікальні умови в межах кожного процесу розглядались впродовж розроблення усіх компонентів плану НАССР. У розробленні плану НАССР існують п'ять попередніх кроків, які представлені на рис.1

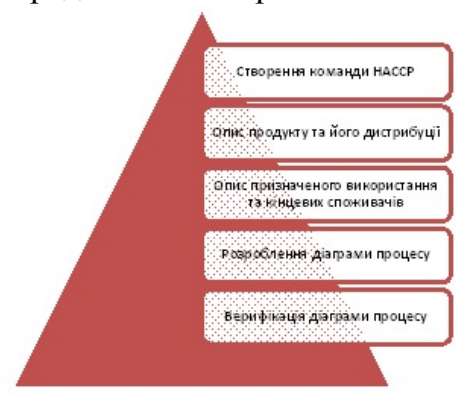

Рис. 1 Аналіз етапів розроблення НАССРплану на підприємстві ПП «Стрийські делікатеси»

Встановлено 7 принципів НАССР, кожний з яких реалізуються під час розроблення НАССР плану:

1. Проведення аналізу небезпек, тобто підготовка переліку кроків виробничого процесу, де можуть виникнути небезпеки, та опис заходів контролю.

2. Визначення критичних точок контролю (CCPs) або етапів, на яких можливий контроль для попередження та усунення небезпек для харчових продуктів або зменшення його до прийнятного рівня.

3. Встановлення критичних меж, які є максимальною та мінімальною величиною, в межах яких необхідно управляти небезпеками в ССР для того, щоб попередити, усунути та зменшити до прийнятного рівня виникнення ідентифікованої небезпеки для харчових продуктів.

4. Встановлення процедур моніторингу, для того, щоб оцінити чи знаходиться ССР під контролем, провести точні записи для подальшого використання під час верифікації.

5. Встановлення коригувальних дій, які будуть виконуватися якщо відбувається відхилення за критичні межі.

6. Встановлення процедур верифікації, щоб визначити чи працює план НАССР у відповідності з встановленими вимогами.

7. Встановлення процедур документування та ведення записів.

Використання цих принципів реалізується через 15 етапів: 
1. Визначення завдань, об'єктів, стратегії, необхідних ресурсів.

2. Збирання команди НАССР.

3. Збирання даних про продукт.

4. Збирання даних про процес.

5. Огляд джерел та даних про небезпеки.

6. Визначення небезпек, пов'язаних з кожним етапом технологічного процесу.

7. Оцінка ризиків.

8. Перерахування потенційних заходів контролю.

9. Визначення критичних точок контролю (CCPs).

10. Встановлення критичних лімітів.
11. Вставлення процедур моніторингу.

12. Встановлення коригувальних дій.

13. Складання Плану контролю за небезпеками.

14. Документування системи НАССР.

15. Верифікація системи.

Ми проводили аналіз існуючого НАССР - план для виробництва варених ковбас, які виготовляються згідно вимог ДСТУ 4436:2005 «Ковбаси варені, сосиски, сардельки, хліби м'ясні. Загальні технічні умови».

Важливі якісні характеристики готового продукту наведено в таблиці 1.

Опис готового продукту

\begin{tabular}{|c|c|}
\hline 1. Назва продукту & Ковбаси варені \\
\hline $\begin{array}{l}\text { 2. Важливі характеристики } \\
\text { продукту }\end{array}$ & $\begin{array}{c}\text { Масова частка білка не менше ніж } 10 \% \\
\text { Масова частка жиру не більше ніж } 32 \% \\
\text { Масова частка вологи не більше ніж } 72 \% \\
\text { Масова частка кухонної солі не більше ніж 2,5\% } \\
\text { Масова частка нітриту натрію не більше ніж } 0,005 \%\end{array}$ \\
\hline $\begin{array}{l}\text { 3. Яким чином він повинен викори- } \\
\text { стовуватися }\end{array}$ & $\begin{array}{l}\text { В якості продукції харчування в межах терміну придатності, вказаної на } \\
\text { упаковці }\end{array}$ \\
\hline 4. Упаковка & Натуральна \\
\hline 5. Умови зберігання & $\begin{array}{c}\text { Варені ковбаси зберігають в холодильних камерах при температурі від } 0 \text { до } 6^{\circ} \mathrm{C} \\
\text { не більше } 72 \text { годин }\end{array}$ \\
\hline 6. Зона розповсюдження & Заклади громадського харчування, роздрібна торгівля \\
\hline 7. Інструкції з маркування & $\begin{array}{c}\text { Найменування та адреса підприємства виробника, повна назва продукту, маса, } \\
\text { склад, інформаційні дані про харчову та енергетичну цінність, термін зберіган- } \\
\text { ня, кінцевий термін реалізації, умови зберігання продукту }\end{array}$ \\
\hline $\begin{array}{l}\text { 8. Спеціальний контроль розповсю- } \\
\text { дження }\end{array}$ & $\begin{array}{l}\text { Спеціальний ізометричний транспорт або з холодильним устаткуванням у від- } \\
\text { повідності з діючими правилами перевезень харчових продуктів. Тривалість } \\
\text { перевезення в ізометричному транспорті повинна не перевищувати } 2 \text { години }\end{array}$ \\
\hline
\end{tabular}

Для харчових продуктів першочергове значення мають показники безпечності для життя та здоров'я людини. Тому продукт повинен відповідати встановленим в чинних нормативних документах вимогам безпеки. Показники безпеки для варених ковбас вказані в таблиці 2.

Показники безпеки для варених ковбас

\begin{tabular}{|l|l|}
\hline \multicolumn{1}{|c|}{ Показник } & \multicolumn{1}{|c|}{ Значення } \\
\hline Важкі метали, мг/кг: & 0,3 \\
свинець, & 0,03 \\
кадмій, & 0,1 \\
миш'як, & 0,02 \\
ртуть, & 5,00 \\
мідь, & 50,00 \\
цинк & Не більше 2,5 × 105 \\
\hline Кількість мезофільних аеробних \\
факультативних анаеробних \\
мікроорганізмів, в 1 г \\
\hline Бактерії роду сальмонели, в 25 г & \\
\hline
\end{tabular}

Наступним етапом $є$ ідентифікація, аналіз та опис ризиків, який проводили за трьома видами небезпек, які наведено в таблиці 3.

Критична точка контролю (КТК) - це етап, на якому можна застосовувати заходи контролю, і який $\epsilon$ суттєвим для запобігання або усунення небезпечних чинників або для зменшення їх до прийнятного рівня. Всі можливі небезпечні чинники, які за умов відсутності належного контролю з великою долею ймовірності можуть призвести до захворювань або ушкоджень, повинні бути розглянуті при встановленні КТК. Повне та точне визначення КТК є основою для контролю небезпечних чинників. Інформація, яка зібрана протягом аналізування небезпечних чинників $\epsilon$ суттєвою для визначення того, які етапи технологічного процесу є критичними точками контролю. Розробляти та документально підтверджувати КТК потрібно уважно. В рамках НАССР КТК повинні встановлюватися з метою забезпечення безпечності продуктів.

Таблиия 3

Класифікація ризиків згідно системи НАССР

\begin{tabular}{|c|c|c|}
\hline Біологічні ризики & Хімічні ризики & Фізичні ризики \\
\hline Патогенні та умовно патогенні & Різноманітні засоби для чищення, пласти- & Сторонні предмети: \\
бактерії, віруси, паразити та найпро- & фікатори, що мігрують з пакувальних матеріа- & - скло; \\
стіші одноклітинні організми, ток- & лів, пестициди, алергени, важкі метали, нітра- & - метал; \\
сини грибкового походження, цвілі, & ти, нітрити, нітрозо сполуки, діоксани, міко- & - каміння; \\
гриби тощо & токсини, харчові добавки, ветеринарні препа- & - дерево; \\
& рати (антибіотики, гормони, тощо) та інше & - пластик, тощо \\
\hline
\end{tabular}


Наприклад, конкретний термічний процес протягом визначеного періоду часу та за визначеної температури, який застосовується для знищення конкретних патогенних мікроорганізмів, може вважатися КТК. Так само, охолодження напівфабрикатів з метою недопущення розмноження патогенних мікроорганізмів, або регулювання рівня $\mathrm{pH}$ у продукті 3 метою запобігання утворення токсинів, також можуть розглядатися як КТК.

Застосування дерева рішень повинно бути гнучким та враховувати особливості технологічної операції, що розглядається. Воно повинно використовуватися як допоміжний інструмент для визначення КТК. В окремих випадках дерево рішень $є$ незастосовним. Використання інших підходів до встановлення КТК також $є$ можливим. Якщо на певному етапі виробничого процесу виявлено суттєвий небезпечний чинник, але а ні на цьому етапі, а ні на інших етапах технологічного процесу не існує заходу 3 контролю такого небезпечного чинника, то на цьому, або попередньому чи подальшому етапах технологічного необхідно внести зміни до продукту або самого процесу так, щоб захід 3 контролю з'явився. Порядок визначення критичних точок контролю представлений на табл. 4.

Таблиия 4

Визначення критичних точок контролю

\begin{tabular}{|c|c|c|c|c|c|c|}
\hline \multirow[b]{2}{*}{$\begin{array}{c}\text { Вхідний } \\
\text { Матеріал / етап процесу }\end{array}$} & \multirow[b]{2}{*}{$\begin{array}{l}\text { Вид та ідентифікована } \\
\text { небезпека }\end{array}$} & \multicolumn{5}{|c|}{ Питання } \\
\hline & & 1 & 2 & 3 & 4 & $\begin{array}{l}\text { Номер } \\
\text { КТК }\end{array}$ \\
\hline Обвалювання м’яса & $\begin{array}{c}\text { Ф - при недотриманні технологій у м'ясо можуть потрап- } \\
\text { ляти скалки кісток, технологічно неправильне відокрем- } \\
\text { лення окремих груп м’язів }\end{array}$ & Так & $\mathrm{Hi}$ & Так & $\mathrm{Hi}$ & KTK -1 \\
\hline $\begin{array}{c}\text { Розведення нітрит } \\
\text { натрію }\end{array}$ & X - дотримання дозувань БКН & Так & $\mathrm{Hi}$ & Так & $\mathrm{Hi}$ & KTK-2 \\
\hline $\begin{array}{c}\text { Варіння } \\
\text { (термообробка) }\end{array}$ & $\begin{array}{c}\text { - Виживання патогенних мікроорганізмів через недотри- } \\
\text { мання належних часових і температурних норм } \\
\text { - Повторне забруднення патогенними мікроорганізмами } \\
\text { через не належний перепад тиску } \\
\text { - Повторне забруднення патогенними мікроорганізмами } \\
\text { через сирі продукти і з причини накопичення продуктів }\end{array}$ & Так & $\mathrm{Hi}$ & Так & $\mathrm{Hi}$ & KTK -3 \\
\hline $\begin{array}{c}\text { Охолодження під } \\
\text { душем }\end{array}$ & Б - контамінація поверхні туші мікроорганізмами & Так & $\mathrm{Hi}$ & Так & $\mathrm{Hi}$ & КТК -4 \\
\hline
\end{tabular}

\section{Висновки}

В результаті проведеного аналізу можна зробити наступні висновки:

1. Сучасною попереджувальною системою, яка забезпечує якість та безпеку харчової продукції, є система на основі принципів НАССР. Виробник може реалізувати свій товар тільки при умові виконання вимог, які відповідають міжнародним стандартам.

2. В роботі проаналізований порядок впровадження НАССР, який включає в себе два етапи: підготовчий етап, та етап впровадження, який включає в себе сім принципів, сформованих у міжнародних стандартах по системі НАССР.

3. Проаналізовано перелік програм-передумов, що $\epsilon$ необхідною умовою для функціонування системи HACCP.

4. Проаналізовано перелік небезпечних чинників, що впливають на якість та безпечність ковбасних виробів.

5. Проаналізовано, на базі дерева рішень 4 критичні контрольні точки які дозволяють усувати або знижувати ризик до мінімуму.

\section{Бібліографічні посилання}

Belov, Ju.P. (2005). Rozrobka ta vprovadzhennja systemy upravlinnja bezpechnistju harchovyh produktiv NASSR. Svit jakosti Ukrai'ny. 2, 42-45 (in Ukrainian).

Gronel', L. (2008). Analiz riskov i kriticheskih to-chek upravlenija. Sertifikacija. M.: VNIIS (in Russian).
Davleev, A., Versan, V.G. (2012). Sistemy analiza riskov i opre-delenija kriticheskih kontrol'nyh tochek. M. (in Russian).

Derzhavnyj komitet Ukrai'ny z pytan' tehnich-nogo reguljuvannja ta spozhyvchoi' polityky «Nakaz pro pryznachennja organiv ta audytoriv z sertyfikacii' system upravlinnja bezpechnistju harchovyh produktiv»» vid 25 serpnja 2004. 185 (in Ukrainian).

Dyman', T.M., Mazur, T.G. (2011). Bezpeka prodovol'choi' syrovyny i harchovyh produktiv. Akademija) (in Ukrainian).

Klymenko, M.M. (2006). Tehnologija m'jasa ta m'jasnyh produktiv: Pidruchnyk. K.: Vyshha osvita (in Ukrainian).

Pid red. Topol'nyc'kogo O.V. (2013). Metodychnyj posibnyk NASSR: Analiz nebez-pechnyh chynnykiv ta krytychni tochky kontrolju dlja pidpryjemstv po vyrobnyctvu harchovoi' produkcii' ta prodovol'choi' syrovyny, K.: Himedzhest (in Ukrainian).

Jakubchak, O.M., Dyman', R.M., Olijnyk, L.V. (2010). Metodychni rekomendacii' shhodo vprovadzhennja. K.: Bio-prom. 40 (in Ukrainian).

Ostrovs'ka, A. (2004). Sertyfikacija harchovyh produktiv: pidvyshhennja jakosti ta bezpeky. Standartyzacija Sertyfikacija Jakist'. 1, 41-42 (in Ukrainian).

Bykov, V.N. [ta in.] (2013). Systema NASSR: dovidnyk. L.: NTC Leonorm. Standart (in Ukrainian).

Alehina, A.S., Bol'shakov, V.G. (2012). Tehnologija mjasa i mjasnih produktov (in Ukrainian).

Стаття надійшла до редакиії 30.09.2016 